ISSN 1507-3866

e-ISSN 2449-9994

\title{
Grzegorz Urbanek
}

University of Lodz

e-mail: grzegorz.urbanek@uni.lodz.pl

\section{ANALYSING BRAND STRENGTH - CORPORATE FINANCIAL PERFORMANCE LINK FOR COMPANIES LISTED ON THE WARSAW STOCK EXCHANGE}

\section{ANALIZA ZWIĄZKÓW POMIĘDZY SILĄ MARKI A WYNIKAMI FINANSOWYMI PRZEDSIĘBIORSTW NOTOWANYCH NA GIEŁDZIE PAPIERÓW WARTOŚCIOWYCH W WARSZAWIE}

DOI: 10.15611/ekt.2017.2.06

JEL Classification: M31, G31, C23

\begin{abstract}
Summary: The opinion that a strong brand is a valuable resource for a company which may significantly influence company performance and contribute to shareholder value creation is gaining wider acceptance. However, empirical studies which confirm this view are relatively few. The purpose of this article is to examine the link between brand strength and corporate financial performance, including shareholder value creation. A number of performance indicators were used in this study - profitability ratios (ROA, ROE, ROIC) and the shareholder value creation proxy indicator $-\mathrm{P} / \mathrm{BV}$. The empirical data regarding brand strength were drawn from the annual ranking of the strength of Polish brands, while the financial data of companies were taken from a panel consisting of 56 companies listed on the Warsaw Stock Exchange, observed over a seven-year period from 2008 to 2014. Numerous regression models were examined in order to test hypotheses on links between brand strength and various financial performance indicators. The obtained results support most of the hypotheses, concluding that there is a statistically significant relationship between brand strength and company performance, although the strength of these relationships differs depending on the type of performance indicator. This study contributes to the development of corporate finance literature as well as value based marketing concepts. Apart from its academic aspects, this paper contributes to business practice development since it demonstrates the legitimacy of marketing investments in brand development.
\end{abstract}

Keywords: brand strength, brand equity, financial performance, shareholders value, profitability ratios.

Streszczenie: Pogląd, że silna marka jest cennym zasobem przedsiębiorstwa, zyskuje coraz szerszą akceptację. Jednak badania empiryczne potwierdzające ten pogląd są stosunkowo nieliczne. Celem niniejszego artykułu jest zbadanie związku pomiędzy siłą marki korporacyjnej 
przedsiębiorstwa a jego wynikami finansowymi oraz tworzeniem wartości dla akcjonariuszy. W badaniu wykorzystano wiele wskaźników rentowności (ROA, ROE, ROIC) oraz wskaźnik tworzenia wartości dla akcjonariuszy - P/BV. W celu przetestowania hipotez na temat związków pomiędzy siłą marki a wynikami finansowymi przedsiębiorstw wykorzystano modele regresji. Uzyskane wyniki wspierają większość hipotez, wskazując, że istnieje statystycznie istotna zależność pomiędzy siłą marki a wynikami finansowymi przedsiębiorstw, z tym że siła tych zależności jest różna dla poszczególnych wskaźników finansowych.

Słowa kluczowe: siła marki, kapitał marki, wyniki finansowe, wartość dla akcjonariuszy, wskaźniki rentowności.

\section{Introduction}

During the era of the knowledge economy, intangible resources are the most important determinants of company success and shareholder value creation. Nowadays the most valuable companies in the world are involved in the, widely understood, service sector and their most valuable assets are intangibles, like knowledge, brands, patents and relations with customers and business partners. The increased contribution of intangible factors to the success of organizations creates new challenges for theorists and practitioners of management, especially in the area of their identification and measurement [Reilly, Schweihs 1999]. The growing importance of "hidden" intangible assets results in a decline in corporate transparency and thus raises difficulties in the assessment of a company's present situation as well as its prospects for the future. As a general rule, the value of intangibles cannot be disclosed on a company's balance sheet unless they were acquired individually, or as a result of the acquisition of a whole business. In that case, intangible assets are disclosed through purchase price allocation in proportion to their fair value.

Among all intangibles, the leading position from the point of view of the ability to create value is held by the brand. For many companies, a strong brand may form the basis for their sustainable competitive advantage, leading to a higher rate of return on invested capital and, consequently, to value creation. Thus, investing in brands should be perceived as a strategy that contributes to improved performance. Hence a result of the appreciation of the brand as a valuable asset, the problem of brand management is no longer the sole domain of marketing and has become a financial issue, being a part of the value based management process.

The aim of this paper is to examine the link between brand strength and the corporate financial performance for companies listed on the Warsaw Stock Exchange. A number of hypotheses were put forward regarding the associations between brand strength and company performance measures. The article begins with theoretical deliberations on the relevance of a brand as an economic asset and its contribution to value creation for both the company and its shareholders. It continues with a literature review of research regarding the impact of the brand on company 
performance. Next, a presentation of the hypotheses and research methodology is presented, followed by a discussion on the results obtained. In the conclusion, any theoretical and managerial implications of the study and directions for future research are discussed.

\section{Literature review}

The issue of the links between the brand and company performance has been analysed in a number of publications worldwide. The subject literature concerning the impact of the brand on company performance concentrates on two main issues: firstly, on the relationships between the brand equity and the value of the company, secondly, on the relationships between the brand equity and the measures of shareholder value creation.

R. Kerin and R. Sethuraman have demonstrated the presence of the positive relation between brand value and the market to book value ratio for firms with valuable brands, according to the Interbrand 1995-1996 ranking [Kerin, Sethuraman 1998]. The research carried out by M. Conchar et. al., has demonstrated the strong positive relationship between advertising and promotion expenses and the market value of a firm. Therefore the connection between brand building activities and the financial performance of a firm has been proved [Conchar et. al. 2005]. C. Simon and M. Sullivan have presented a method utilising the market value of a company as the basis for the valuation of the brand equity. The calculation conducted by the authors has shown that the value of the brand equity may constitute as much as $150 \%$ of the replacement value of companies [Simon, Sullivan 1993]. D. Aaker and R. Jacobsen's research has indicated that the "perceived quality" measure, which is an indicator of brand equity, is statistically, significantly and positively correlated with changes in share price [Aaker, Jacobsen 1994]. M.Barth et al. have proved that the value of the brand is significantly and positively correlated with both share prices and return on shares [Barth et al. 1998].

The research findings quoted above generally indicate the existence of the positive relation between brand equity and company value. Therefore they allow the understanding of the relations that occur between the brand and company value as well as (indirectly) shareholder value. As mentioned above, the creation of shareholder value is not identical with achieving a positive return on shares and the increased market capitalisation of the company. From the shareholders' point of view, value is generated when the achieved return is higher than that possible from an alternative investment with similar risk. This issue has been covered in more recent studies on the links between the brand and shareholder value creation.

According to N. Mizik and R. Jacobson's research (275 companies with a single brand over a period of 11 years), companies that increased the differentiation of their brands have managed to receive a return on shares (risk adjusted) to the amount of $4.8 \%$, while companies that reduced the differentiation of their brands have managed 
(risk adjusted) a negative return on shares of 4.3\% [Mizik, Jacobson 2005], the above effects occurring with a one-year delay. These results mean that companies which managed to increase their strength (differentiation) achieved a higher than expected shareholder return and vice-versa. The research conducted by T. Madden, et al., has indicated that companies with valuable brands (according to the Interbrand 1994-2000 ranking) have managed to achieve a higher monthly return on shares than the average return for the market, at a lower than average risk [Madden et al. 2006].

\section{Brand and company performance}

The term "brand", depending on the context, can have different meanings. According to the "classic" marketing definition - a brand is a particular name, term, sign or symbol or a combination of the above designed to identify the product or service of a seller or a group of sellers and distinguish it from those offered by the competitors [Kotler, Armstrong 2004]. The brand indicates to the consumer the origin of a product or service and protects both customer and manufacturer from competitors who may offer products which look identical. From the perspective of brand contribution to value creation, a brand should be treated as an economic category, generating identified benefits for the owner of the brand. These benefits take the form of additional cash flow above that which would be possible with the sale of analogical, unbranded products.

Brands, in different forms, have been around in business reality since ancient times, however they received a wider interest in the mid-1980s in connection with the numerous acquisitions of companies. These transactions were characterised by the fact that the acquisition price of many companies considerably exceeded the value of their net assets. The main part of this surplus was attributed to the value of the brands owned by the target companies, which were not disclosed on their balance sheets [Murphy 1990]. The increased interest in brands caused the appearance of a number of research projects and publications on that subject. Initially, publications on brands focused mainly on the issues related to the attempt to break it down into components and explain the impact of the brand on consumer behaviour. A breakthrough publication in this field turned out to be D. Aaker's book on brand equity, in which the author introduced the term brand equity as the sum of assets associated with the name and the symbol of the brand which may be the source of certain benefits for both parties of a transaction: companies (brand owners) and customers (brand consumers) [Aaker 1991]. Later, greater research pressure was put on the issues of the methods of brand valuation and, subsequently, brand impact on company performance and shareholder value creation [Salinas 2009]. The latter problem is a component of a broader field of research related to the issue of the measurement of marketing activity effectiveness [Rust et al., 2004]. This relatively recent research direction is a result of the profound changes that have taken place in the business environment since the turn of the century. Globalisation and the dissemination of 
the Internet and IT technologies have caused the intensification of competition and, at the same time, a growing emphasis on increasing the efficiency of companies. Under these conditions, increased pressure has been put on the need to improve the effectiveness of any operations conducted in a company, since the contemporary competitive environment punishes companies for any sign of mismanagement and inefficiency. As a result, any actions, for example those related to investment in brand building, must be supported by a reliable profitability analysis in order to receive approval.

The theoretical substantiation of the relations between a strong brand and company value is well grounded in the theory of value creation [Doyle 2008]. A theoretical model of the impact of market assets, including the brand, on shareholder value has been presented in the, already, classic article written by R. Srivastava, T. Shervani and L. Faley [Srivastava et al. 1998]. A strong brand may affect four sources of revenue and cash flow generation for the company: an increase in the number of customers, an increase in the brand being used by existing customers, an increase in the loyalty of customers and the possibility of an extension of the brand use to new products [Schultz, Schultz 2003]. The cause-and-effect link between a strong brand and company performance and shareholder value can be summarized using the following structure (Figure 1).

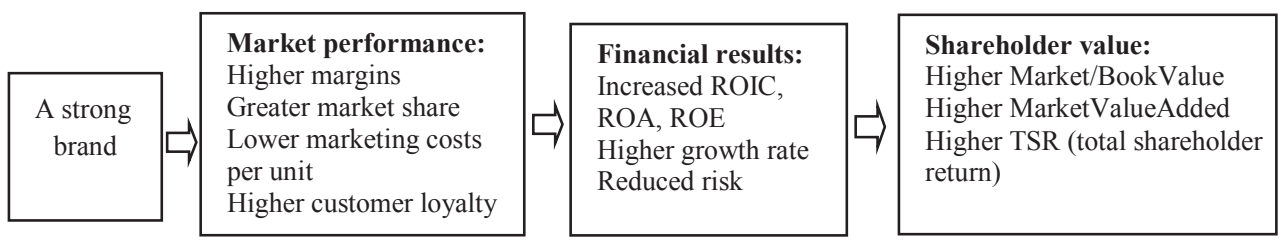

Fig. 1. The brand - company performance and shareholder value link

Source: own study.

The impact of the brand on company value can also be analysed with a financial model which identifies the key determinants of value creation. This model, in its basic form, is represented by the following equation [Koller et al. 2005]:

$$
\text { value }=I C_{0}+\frac{\text { EconomicProfit }}{1} \text {, }
$$

where: $I C_{0}$ - invested capital, EconomicProfit ${ }_{1}=I C_{0} \times(R O I C-w a c c)$; wacc - weighted average cost capital; ROIC - return on invested capital; $g$ - operating profit growth rate.

According to the equation above, a firm's value equals the book value of its invested capital plus the present value of future economic profits. The brand may affect positively a company's profitability (ROIC) and, consequently, its future economic 
profits. The higher the economic profits, the higher the company's market value in relation to its book value. The brand can also affect the volatility of a company's profits (lower wacc). In the latter case, the high level of customer loyalty contributes to stability in the profitability of a company, thus reducing its risk. Brands also serve as a unique channel of communication with investors. Investors prefer shares of companies that have brand exposure on the market. This causes growth in the number of shareholders, which improves share liquidity and, as a consequence, leads to a decrease in the cost of equity [McAlister et al. 2007]. Thus, one method to verify links between brand strength and firm performance could be the analysis of associations between price/book value ratio and brand strength index.

Nevertheless, the relations between marketing activities directed at brand building and company performance are not straightforward. This is because company performance can be understood through both short-term results - profitability, and long-term results - shareholder value creation. The use of these two perspectives to assess the performance of a company may lead to conflicts in decision making. Maximising profitability in the short-term, for example through cutting costs on marketing, usually leads to a deterioration in the long-term competitive position of a company and, finally, a reduction in shareholder value creation. On the other hand, poor results in periodical profitability may not always be excused by long-term value creation orientation. Therefore the justification of brand oriented strategies should be made through evidence that they contribute to maximising shareholder value. Only then will weaker interim results be accepted.

Based on the above deliberation on the associations between brand strength and company financial performance, we put forward the following hypotheses:

\section{Hypothesis 1}

There is a positive association between brand strength and company performance measures - ROA, ROE, ROIC.

\section{Hypothesis 2}

There is a positive association between brand strength and shareholder value creation measure $-\mathrm{P} / \mathrm{BV}$.

\section{Hypothesis 3}

Associations between brand strength and shareholder value creation measures $(\mathrm{P} /$ $\mathrm{BV}$ ) are stronger than the associations between brand strength and current period profitability measures. 


\section{Research method}

\section{Sample}

The sample utilized in this study consists of 56 Polish companies listed on the Warsaw Stock Exchange between 2008 and 2014. Companies for this research were selected based on the availability of data on brand strength index. Brand strength index is calculated for the ranking of the most valuable Polish brands and has been published annually since 2004 by "Rzeczpospolita" daily. Due to the availability of data, the sample concentrates on companies belonging to the following industries: clothing and footwear, food products, media, banking, industrial products and house construction. Financial data were derived from the Thomson Datastream database and collected manually from annual financial reports. In this study, observations with a negative book value and with missing data were eliminated. This led to an unbalanced initial panel sample of 56 companies from 272 to 318 firm-year observations, depending on the analyzed model. To alleviate the influence of outlying values, extreme observations were excluded by rejecting the top and bottom $1 \%$ of observations for each dependent variable.

\section{Models and variables}

The following model was used for testing the hypothesis:

$$
Y_{i}=\alpha_{i}+\beta X_{i}+\gamma Z_{i}+\varepsilon_{i,}
$$

where: the $Y_{i}$ vector contains the dependent variables. i.e. return on assets (ROA) - model 1, return on equity (ROE) - model 2, economic profit margin (ROIC) model 3, and Price/Book value ratio $(\mathrm{P} / \mathrm{BV})-$ model 4 . The $X_{i}$ vector includes the independent variable, brand strength index (BSI). The $Z_{i}$ vector consists of the control variables which can have an influence on company performance, specifically, company size (total assets transformed with a natural logarithm - LnA), leverage (the ratio of total liabilities to total assets - DT), industry index (IndI) and finally, $\varepsilon_{i t}$ describes random disturbance. Since the data covered a seven year period, they were subjected to panel data analysis. Based on the results of the Wald, Breusch-Pagan and Hausman tests, an ordinary least squares regression was selected for models 1 and 3, and fixed-effect regression was selected for models 2 and 4 . The results of all the tests are presented in Table 2.

\section{Independent variables}

In this study, brand strength index (BSI) is taken from the annual ranking of the most valuable Polish brands. Brand strength is determined by comparing its position with competing brands, based on the results of market research conducted on a representative sample of adult consumers in Poland. Brand strength is a multidimensional construct based on nine individual indicators: consumer preferences, brand awareness, priority in mind, brand loyalty, brand references, perceived brand quality, brand prestige, brand value (perception of price in relation to quality) and industry 
affiliation. Each of these areas was assigned a weight by a panel of experts. The sum of weights is 100 . The brand strength index fits in intervals from 0 to 100 points. A score of 100 points is for the ideal brand on the Polish market, while 0 points is assigned to a brand of null significance. The industry affiliation indicator is also used in this study as a separate control variable, its value differentiates the significance of the brand in various sectors.

\section{Control variables}

The choice of control variables was motivated by their potential relevance. The factors controlled include firm size, debt ratio and industry affiliation. Since firm performance is associated with firm size, total assets are used to control the latter. As is common practice, these data are transformed by a natural logarithm. Firm leverage is controlled by the debt ratio, calculated as the ratio of total liabilities to total assets. This control variable is of particular importance in assessing corporate performance, as it is affected by capital structure. The industry affiliation variable is used to control the company sector, since the importance of the brand is different in various sectors. The maximum value of this variable i.e. 8.947, is assigned for brands from the clothing and footwear industry, while a minimum value of 0.737 is assigned for industrial product brands.

\section{Results}

\section{Descriptive statistics and correlation}

Table 1 presents the descriptive statistics and correlation matrix for the variables considered. The mean of return on assets (ROA) is 0.0321 , the mean of return on equity (ROE) is 0.0651 and the mean of return on invested capital (ROIC) is 0.0522 . The mean of $\mathrm{P} / \mathrm{BV}$ ratio is 1.72 , with standard deviation of 1.9525 , which indicates that, on average, companies in the sample possess an excess of market value over book value. The mean of brand strength index (BSI) across the entire sample is 54.86 , with standard deviation of 9.24. Because the range of variation for the brand strength index is from 0 to 100 points (with an average of 50 points), the analyzed brands in the sample are above average in regard to brand strength index. The mean of debt ratio (DT) is 0.3926 .

Correlation analysis provides an initial preview for the analysis of associations between dependent and independent variables. Table 2 shows the results of the Pearson pair-wise analysis, which indicates that the brand strength index (BSI) is significantly and positively associated $(\mathrm{p}<0.01)$ with price/book value $(\mathrm{P} / \mathrm{BV})$ and return on equity (ROE). The brand strength index (BSI) is not significantly associated with return on assets (ROA) and return on invested capital (ROIC). Consequently, the results of the correlation analysis entirely support hypotheses 2 and 3, and partially support hypothesis 1 . 
Table 1. Descriptive statistics and correlation matrix

\begin{tabular}{|l|l|l|l|l|l|l|l|l|l|l|}
\hline & Mean & S.D. & ROA & ROE & P/BV & ROIC & BSI & IndI & DT & LnA \\
\hline ROA & 0.0321 & 0.0859 & 1.00 & & & & & & & \\
\hline ROE & 0.0651 & 0.1620 & $0.876^{* *}$ & 1.00 & & & & & & \\
\hline P/BV & 1.7202 & 1.9525 & $0.247^{* *}$ & $0.249^{* *}$ & 1.00 & & & & & \\
\hline ROIC & 0.0522 & 0.1447 & $0.928^{* *}$ & $0.920^{* *}$ & $0.329^{* *}$ & 1.00 & & & & \\
\hline BSI & 54.86 & 9.24 & 0.080 & $0.152^{* *}$ & $0.294^{* *}$ & 0.100 & 1.00 & & & \\
\hline IndI & 5.24 & 2.71 & -0.065 & -0.041 & $0.163^{*}$ & -0.052 & $0.204^{* *}$ & 1.00 & & \\
\hline DT & 0.3926 & 0.3322 & $-0.372^{* *}$ & -0.057 & 0.005 & $-0.332^{* *}$ & 0.021 & $0.136^{*}$ & 1.00 & \\
\hline LnA & 14.27 & 2.14 & 0.025 & $0.123^{*}$ & 0.028 & $0.148^{*}$ & $-0.212^{* *}$ & $-0.528^{* *}$ & -0.089 & 1.00 \\
\hline & & & & & & & & & & \\
\hline
\end{tabular}

Note: Significant at $\mathrm{p}<0.05^{*} ; \mathrm{p}<0.01^{* *}$.

Source: author own calculations.

\section{Regression analysis}

After initial testing of the proposed hypotheses with correlation analysis, the next step is testing hypotheses through linear multiple regression models. The correlation coefficients between explanatory variables used in individual models are not high. They range from -0.528 to 0.148 . This allows the presumption of the absence of any multicollinearity. Table 2 exhibits the results of the regression coefficients for all explanatory variables, including the control variables - size, leverage and industry affiliation.

The coefficients of determination for the tested models vary from $R^{2}=0.1448$ (model 1) to $R^{2}=0.3883$ (model 4 ). This shows that the explanatory power of model 4 is the highest among all the tested models. The results from the analysis of the coefficients of determination for all the tested models support hypotheses 3 . In model 1, independent variable BSI and control variables IndI and LnA are not significantly associated with ROA, while control variable DT has a negative and significant impact on the return on assets ROA ratio $(\mathrm{p}<0.01)$. In model 2 , independent variable BSI has a positive and significant impact on ROE $(\mathrm{p}<0.01)$, control variable DT has a negative and significant impact on $\operatorname{ROE}(\mathrm{p}<0.01)$, while control variables IndI and LnA are not significantly associated with the dependent variable. Also, in model 3, independent variable BSI has a positive and significant impact on ROIC $(p<0.05)$, control variable DT has a negative and significant impact on the dependent variable $(\mathrm{p}<0.01)$, control variable LnA has a positive and significant impact on the dependent variable $(p<0.01)$, while control variable IndI is not significantly associated with dependent variable ROIC. The results from model 1, 2 and 3 support hypothesis 1 in respect to ROE and ROIC ratios but fail to support hypothesis 1 in respect to ROA ratio. Finally, in model 4, independent variable BSI has a positive and significant impact on $\mathrm{P} / \mathrm{BV}(\mathrm{p}<0.01)$. There is also a positive and significant impact of control 
Analysing brand strength - corporate financial performance link...

Table 2. Results of panel estimation ( models 1 and 3 - OLS; models 2 and 4 - fixed effects)

\begin{tabular}{|l|c|c|c|c|}
\hline \multirow{2}{*}{$\begin{array}{c}\text { Independent } \\
\text { variables }\end{array}$} & \multicolumn{4}{|c|}{ Dependent variables } \\
\cline { 2 - 5 } & $\begin{array}{c}\text { Model 1 } \\
\text { ROA }\end{array}$ & $\begin{array}{c}\text { Model } 2 \\
\text { ROE }\end{array}$ & $\begin{array}{c}\text { Model 3 } \\
\text { ROIC }\end{array}$ & $\begin{array}{c}\text { Model 4 } \\
\text { P/BV }\end{array}$ \\
\hline Constant & 2.6309 & -11.2250 & $-19.2833^{* *}$ & $-5.8577^{* * *}$ \\
& $(4.9301)$ & $(12.1054)$ & $(9.1387)$ & $(1.4463)$ \\
\hline Brand strength (BSI) & 0.0668 & $0.4230^{* * *}$ & $0.2306^{* *}$ & $0.0759^{* * *}$ \\
& $(0.0472)$ & $(0.1176)$ & $(0.0916)$ & $(0.0134)$ \\
\hline Industry index (IndI) & -0.0834 & -0.1814 & 0.1529 & $0.1499^{* * *}$ \\
& $(0.1863)$ & $(0.4829)$ & $(0.3475)$ & $(0.0563)$ \\
\hline Ln assets (LnA) & 0.0864 & 0.0526 & $1.2155^{* * *}$ & $0.1847^{* *}$ \\
& $(0.2425)$ & $(0.6497)$ & $(0.4353)$ & $(0.0774)$ \\
\hline Debt ratio (DT) & $-0.0999^{* * *}$ & $-0.1493^{* * *}$ & $-0.1634^{* * *}$ & 0.0001 \\
& 0.0144 & $(0.0497)$ & $(0.0277)$ & $(0.0057)$ \\
\hline $\mathrm{N}$ & 318 & 315 & 272 & 307 \\
\hline $\mathrm{R}^{2}$ & 0.1448 & 0.2823 & 0.1515 & 0.3883 \\
\hline Wald test & $\mathrm{F}=1.2918$ & $\mathrm{~F}=1.5153$ & $\mathrm{~F}=1.0598$ & $\mathrm{~F}=1.8190$ \\
& $\mathrm{p}=0.0976$ & $\mathrm{p}=0.0176$ & $\mathrm{p}=0.3766$ & $\mathrm{p}=0.0011$ \\
\hline Breusch-Pagan test & $\mathrm{LM}=0.2224$ & $\mathrm{LM}=1.3931$ & $\mathrm{LM}=0.0157$ & $\mathrm{LM}=8.6439$ \\
& $\mathrm{p}=0.6371$ & $\mathrm{p}=0.2379$ & $\mathrm{p}=0.9004$ & $\mathrm{p}=0.0033$ \\
\hline Hausman test & $\mathrm{x}$ & $\mathrm{H}=30.7647$ & $\mathrm{x}$ & $\mathrm{H}=29.6814$ \\
& & $\mathrm{p}=0.0000$ & & $\mathrm{p}=0.0000$ \\
\hline
\end{tabular}

Note: $\uparrow \mathrm{p}<0.1^{*} ; \mathrm{p}<0.05^{* *} ; \mathrm{p}<0.01^{* * *}$. Standard error is given in brackets.

Source: author own calculations.

variables IndI and LnA on P/BV ratio (respectively: $p<0.01$ and $p<0.05$ ), while control variable DT has no significant impact on P/BV. The results from model 4 support hypothesis 2 .

It is worth noting the fact that in models 1,2 and 3 no statistically significant impact of industry affiliation on profitability ratios was identified. This may lead to the conclusion that the profitability of companies does not depend on the industry. This surprising conclusion may result from the adoption of incorrect weights in variables describing industry affiliation. However in model 4, industry affiliation has a statistically significant impact on $\mathrm{P} / \mathrm{BV}$ ratio. This may indicate that the analysis of the associations between brand strength and shareholder value creation should perhaps be conducted separately for each industry.

\section{Conclusions}

Since a brand is recognized as an important determinant of company performance, it is essential to examine the possibilities of improving its effectiveness. In view of 
this, the paper investigates the relationship between brand strength and company performance, understood in terms of profitability and created value for shareholders. This study is complementary to other research on that subject and also helps to understand the differences in the strength of brand impact on the present (profitability) and long-term (shareholder value creation) performance of a company.

A positive and significant relationship between brand strength and ROE, ROIC and $\mathrm{P} / \mathrm{BV}$ ratios was found. Moreover, a stronger relationship between brand strength and shareholder value proxy $-\mathrm{P} / \mathrm{BV}$, than between brand strength and profitability ratios was identified. These findings are in line with expectations, as the brand is regarded as a strategic asset of the company which contributes to long-term value creation.

The results of the presented study are subject to limitations associated with the availability of data and the measurement of variables. Due to the limited availability of data on brand strength, the analysis was conducted on a limited number of companies (56) across six industries. The second limitation concerns the measurement of the industry affiliation variable. Each industry was assigned a weight from the interval $0-10$, reflecting the impact of the brand in the industry. These weights were assigned based on the subjective judgment of experts.

This study indicates the possible directions and areas for further research in this field. It may be interesting to examine the relationship between brand strength and company performance in different industries. Such research would help to identify the industries with the highest brand impact.

\section{Literature}

Aaker D., 1991, Managing Brand Equity, The Free Press, New York.

Aaker D., Jacobsen R., 1994, The financial information content of perceived quality, Journal of Marketing Research, 31, Spring, pp. 191-201.

Barth M., Clement M., Foster G., Kasznik R., 1998, Brand values and capital market valuation, Review of Accounting Studies, 3, pp. 41-68

Conchar M., Crask M., Zinkhan G., 2005, Market valuation models of the effect of advertising and promotional spending: a review and meta-analysis, Journal of the Academy of Marketing Science, vol. 33, no. 4, pp. 445-460.

Doyle P., 2008, Value-Based Marketing, Wiley, Chichester.

Kerin R., Sethuraman R., 1998, Exploring the brand value - shareholder value nexus for consumer goods companies, Journal of the Academy of Marketing Science, vol. 26, no. 4, pp. 260-273.

Koller T., Goddart M., Wessels D., 2005, Valuation: Measuring and Managing the Value of Companies, John Wiley \& Sons, Hoboken.

Kotler P., Armstrong G., 2004, Principles of Marketing, Prentice Hall, Englewood Hall.

Madden T., Fehle F., Fournier S., 2006, Brands matter: an empirical demonstration of the creation of shareholder value through branding, Journal of the Academy of Marketing Science, vol. 34, no. 2, Spring, pp. 224-235.

McAlister L., Srinivasan R., Kim M., 2007, Advertising, Research and Development, and Systematic Risk of the Firm, Journal of Marketing, vol. 71, pp. 35-48. 
Mizik N., Jacobsen R., 2005, Talk About Brand Strategy, Harvard Business Review, September, pp. 24-25.

Murphy J., 1990, Brand Strategy, Prentice Hall, New York.

Reilly R.F., Schweihs R.P., 1999, Valuing Intangible Assets, McGraw Hill, New York.

Rust R., Ambler T., Carpenter G., Kumar V., R. Srivastava, 2004, Measuring marketing productivity: current knowledge and future directions, Journal of Marketing, October, pp. 76-89.

Rzeczpospolita, 2014, Ranking najcenniejszych polskich marek, dodatek z dnia 10 grudnia.

Salinas G., 2009, The International Brand Valuation Manual, Wiley, Chichester.

Schultz D., Schultz H., 2003, IMC The Next Generation - Five Steps for Delivering Value and Measuring Returns Using Marketing Communication, McGraw Hill, Boston.

Simon C., Sullivan M., 1993, The measurement and determinants of brand equity: a financial approach, Marketing Science 12, Winter, pp. 28-52.

Smith G., Parr R., 2000, Valuation of Intellectual Property and Intangible Assets, John Wiley \& Sons, New York.

Srivastava R., Shervani T., Faley L., 1998, Market-based assets and shareholder value: a framework for analysis, Journal of Marketing, 62, pp. 2-18. 